\title{
山口県における夏期の対流性降雨の特徵
}

\author{
鈴木賢士・早川誠而 \\ ( 山口大学農学部生物資源環境科学科)
}

\section{Convective Precipitation in Yamaguchi Prefecture in Summer}

\author{
Kenji SuZUKI, and Seiji HaYAKaWA
}

(Faculty of Agriculture, Yamaguchi University, Yamaguchi 753-8515 Japan)

\begin{abstract}
Convective precipitations in summer often cause agricultural damage by hailfall. On the other hand, it plays an important role as the water resources for agriculture. In this study, we examined the characteristics of summertime convective precipitation in Yamaguchi Prefecture, using the Japan Meteorological Agency weather radar data from 1989 to 1998.

High frequency of radar echo appearances concentrated on the mountainous areas in Yamaguchi Prefecture. First radar echoes appeared frequently around 14JST, and it was 2-4 hours earlier than that observed in Kanto district. Averaged lifetime of radar echoes was 95 minutes, and it was shorter than that in Kanto district. Some of long-lasting ( $>2$ hours) radar echoes had the maximum radar echo area over $500 \mathrm{~km}^{2}$. Sea breeze wind patterns were detected based on the AMeDAS stations just before the first radar echo appearances. This suggested that the convective precipitation in Yamaguchi Prefecture was triggered by the land-sea breeze circulation. Compared with that in Kanto district, the summertime convective precipitation in Yamaguchi Prefecture had smaller temporal and spatial scales.

Key words: Convective precipitation, Lifetime, Radar echo, Rainfall distributions, Yamaguchi Prefecture

キーワード : 夏期対流性降雨, 降水分布, 寿命, レーダーエコー, 山口県
\end{abstract}

\section{1.はじめに}

夏期の対流性降雨は夕立としてよく知られているが，し ばしば落雷や降霞などの激しい気象現象を伴い農業生 産に多大な被害をもたらすだけでなく, 一方で貴重な水 資源としても我々の生活に密接に関係している。農業気 象学における降雹に関する研究は古くから行われており, Omoto (1968; 1970; 1971) や Sakanoue (1969) は事 例解析や統計解析により降霖現象について調べている。 降電による農作物への被害という視点からは, 現地調査 に基づく農学物の被害率の算出に関する研究 (Omoto and Seino, 1978) や, 雹の粒径分布と被害の関係に関 する研究 (Seino, 1980), 降霖による小麦や大豆の被害 の実験的研究 (Seino, 1985) がある。また, 気象学的な 見地からは, 群馬県における降雹を伴う積乱雲の出現特 性に関する研究 (Iwasaki and Ohbayashi, 1998) やレー

2006 年 4 月 27 日 受付, 2006 年 7 月 18 日 受理
ダーデータによる中部関東域の対流性降雨の日変化に関 する研究 (Saitoh and Kimura, 1998) などがある。ま た近年では, 特に関東地方において, 夏期の午後に発達 する対流性降雨と局地風循環や都市のヒートアイランド現 象に注目した研究 (Fujibe et al., 2003; Nakanishi and Hara, 2003; Nakanishi and Sugaya, 2004)や, 対流性 降雨に伴ってしばしば発生する落雷に関する研究 (Ogura et al., 2002a, b; Taguchi et al., 2002) も行われている。 しかしながら, これらの多くは関東地方を対象としたもの であり, 山口県のようなより小さなスケールで発生する対 流性降雨に関する研究は少ない。

山口県は本州の西端に位置し, 三方を海に囲まれ, 中 央に中国山地南西端がかかるという地理的特徴を持って おり, 夏期には対流性降雨がしばしば発生する。農作物 災害種別被害統計 ( 農林水産省統計情報部) によると, 山口県に扔いて 1976 年から 2000 年に発生した霄害に よるのべ被害面積はそれぞれ, 雑穀・豆類 17 ha, 野菜 
79 ha, 果樹 117 ha, 工芸農作物 32 ha, 桑 1 ha であ り, 被害は小さいものの降雹被害が報告されている。そ の発生時期の大半は 4 月から 6 月の梅雨期以前に集中 しているが, 関東地方や九州北部では梅雨期以降の暖 候期後半 (7 月から 9 月) にも霞被害が報告されている ように(Omoto, 1968; Sakanoue, 1969; Iwasaki and Ohbayashi, 1998), 山口県においても降霖や落雷をも たらすような対流性降雨は梅雨明け以降の夏期にもしばし ば発生する。このような降水分布の理解にはレーダーデー タが有効である。AMeDAS のような地上気象観測では 空間分解能が粗すぎて, 夏期の対流性降雨のような擾乱 を十分に捉えることができない。レーダーは大気中の降 水粒子を捉えるため必ずしも地上の降雨と一致しないが, 広範囲に渡って AMeDAS よりも密な分解能で降雨を捉 えることができるという利点がある。降雹や落雷に対する 防災という点に打いて, また, 夏期の貴重な水資源という 点からも, いつどこでどのような降雨があるのかを知るこ とは重要である。そこで本研究では, 山口県における夏 期の対流性降雨の分布, 発生, 移動抢よびその寿命を明 らかにすることを目的として, 1989 年から 1998 年の 10 年間の気象庁北部九州合成レーダーデータを用いて解析 を行った。

\section{2. データ}

対流性降雨の解析には, 気象庁北部九州合成レーダー データを用いた。レーダーデータは 1 時間に 8 回 (毎 時 $00,07,15,22,30,37,45,52$ 分) 得られる $2 \mathrm{~km}$-CAPPI の $2.5 \mathrm{~km} \times 2.5 \mathrm{~km}$ データで, 7 段階 のエコーレベル (降雨強度 $0,1,4,16,32,64,64$ $\mathrm{mm} / \mathrm{h}$ 以上に相当) で構成されている。東経 130.685 132.286 度, 北緯 $33.711 \sim 35.050$ 度で囲まれた山口 県とその周辺を含む $150 \mathrm{~km} \times 150 \mathrm{~km}$ を解析対象域と し (Fig. 1), 1989 年から 1998 年の 7 月から 9 月を解析 対象期間とした。解析対象範囲内に押いて早朝降雨が認 められず, その後局所的な降雨が認められること, 降水 エコーがその出現から 30 分以上連続していることを条件 とし, 地上天気図抢よび気象衛星画像を参照して, 低気 圧や前線, 台風に伴う降雨を取り除いた。解析対象期間中, 50 日で対流性降雨を抽出し, 合計 113 のレーダーエコー (降雨域)を解析対象とした。レーダーエコーの位置の決 定については, 複数の格子点でレーダーエコーが存在す る場合は, その中心を降水エコーの発生および移動を解 析するための情報として用いた。

本研究で用いたレーダーデータは $2.5 \mathrm{~km}$ の空間分解 能を持っているが, 対流性降雨の発生抢よびその発達に ついて十分表現できるかという疑問は残る。しかしながら，

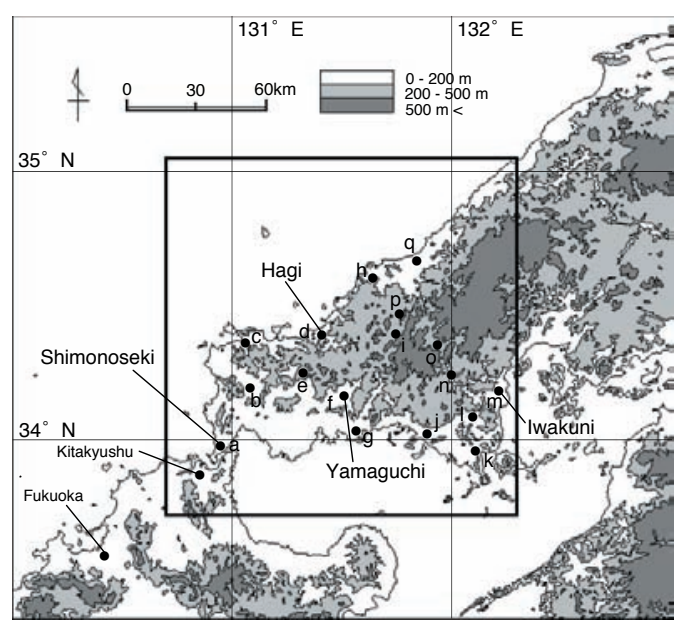

Fig. 1. Map around Yamaguchi Prefecture with the contours of $200 \mathrm{~m}$ and $500 \mathrm{~m}$ above the sea level. Solid box indicates the analysis area in this study. Alphabets indicate AMeDAS stations; a: Shimonoseki, b: Toyoda, c: Yuya, d: Hagi, e: Akiyoshidai, f: Yamaguchi, g: Hofu, h: Susa, i: Tokusa, j: Kudamatsu, k:Yanai, 1: Kuga, m: Iwakuni, n: Hirose, o: Muikaichi, p: Tsuwano, q: Masuda.

本研究ではレーダーエコー分布を降水分布として議論を 進めるとともに, 最初に出現したエコー (初期降水エコー) を初期降水域とする。夏期の対流性エコーは孤立したエ コー域として発生することが多いが, その後の発達はさま ざまである。Iwasaki and Ohbayashi(1998) が述べてい るように, 融合するタイプ, 分裂するタイプがあるが, 本 研究では, 複数の孤立したエコー域が融合した場合, そ の源となるレーダーエコーのうち, より早く発生したものが その後連続して発達したものとして取り扱い, 時間的およ び空間的に連続しないエコーの出現については分裂とは せず, 新しいエコーの発生として取り扱うこととする。レー ダーエコー発生については 113 事例, そのうち寿命やエ コ一面積の解析には, 融合した事例, 判定不可能の事例 を除く 105 事例を用いた。

また, 下関, 豊田, 油谷, 萩, 秋吉台, 山口, 防府, 須佐, 徳佐, 下松, 柳井, 玖珂, 岩国, 広瀬, 六日市, 津和野, 益田の 17 地点における AMeDAS データを解析に用いた。

\section{3. 結果および考察}

\section{1 対流性降水エコー出現の空間分布}

Fig. 2 は解析対象の 50 日中の全 113 事例について, エコーレベル 1(降雨強度 $1 \mathrm{~mm} / \mathrm{h}$ に相当) 以上および エコーレベル 3(降雨強度 $16 \mathrm{~mm} / \mathrm{h}$ に相当) 以上のレー 
ダーエコーが出現したのべ回数の分布を示す。気象庁レー ダーは 7.5 分に 1 回の観測を行っているので, 図中の等 值線はのべ降水時間を示していると考えてよい。エコーレ ベル 1 以上の降水が発生した分布は Fig. 1 に示す標高 $200 \mathrm{~m}$ および $500 \mathrm{~m}$ の等高線に沿う分布をしており, 島 根県境付近の冠山山地に極大值を持ち, 高い出現分布は 山口県中西部抢よび南西部に延びている。エコーレベル 3 以上の強い降水域は, エコーレベル 1 以上の分布に類 似している。Fig. 3 は解析対象 50 日のうちエコーレベル 1 および 3 以上のレーダーエコーの出現した日数を示す。 分布は Fig. 2 とほぼ等しく, 島根県境付近では 50 日中 15 日以上で $1 \mathrm{~mm} / \mathrm{h}$ の降水がみられる。標高 $200 \mathrm{~m}$ 以 上の地域では全解析対象日の 1 割程度で降水がみられる。 エコーレベル 3 以上の強い降水も同様の分布をしており, 島根県境付近では全期間の 2 割程度の日で強い降水がも
たらされている。一般に夏期の対流性降雨は山岳域での 出現が顕著であることが知られているが，山口県において もその傾向が認められた。

Fig. 4 は, 初期降水エコーの発生地点を午前中, 12 時から 14 時, 14 時から 16 時, 16 時以降の時間帯別 に示したものである。午前中に発生した例を除き，初期 降水エコーの発生地点には時間帯による違いが見られず, 島根県境付近の冠山山地を中心とした山口県中央を東西 に延びる「へ」の字状を呈し, (1)島根県境付近 (冠山山地) (2)山口県中西部山地 (秋吉台～萩付近), (3)山口県東部 山地 (周南北部付近)，に集中して分布している。(2) いては標高 $150 \mathrm{~m}$ から $300 \mathrm{~m}$ と比較的低い地域であり, (3)については中国山地南西端の南斜面に位置していると いう特徵を持つが，Iwasaki and Ohbayashi (1998)や Saitoh and Kimura (1998) が述べている関東地方でみ
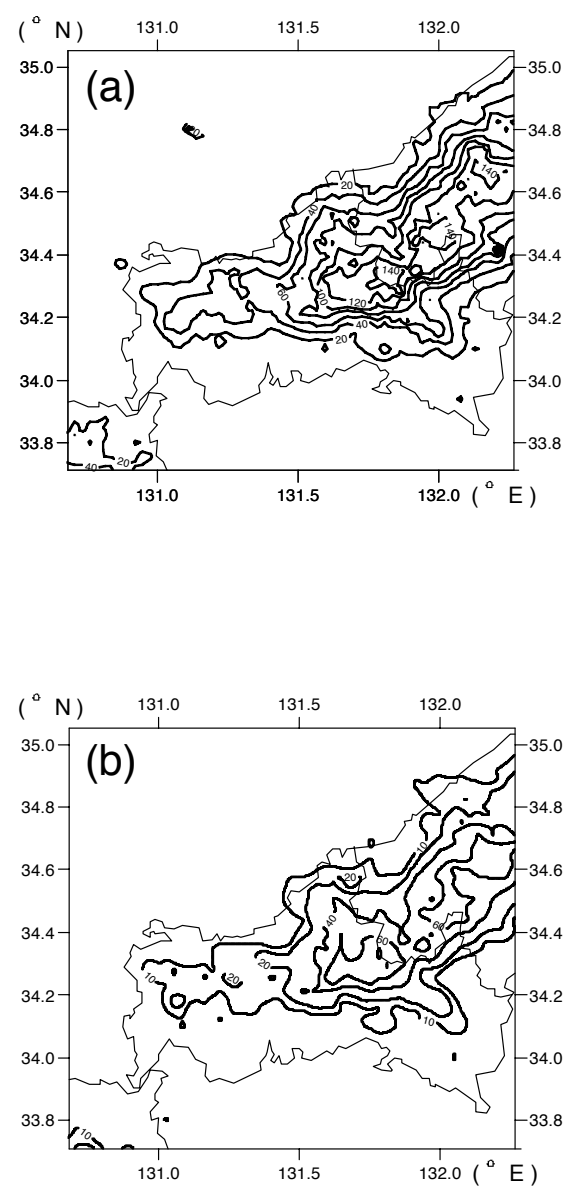

Fig. 2. Total number of the radar echo appearances of (a) $>$ echo level-1 (equivalent to $1 \mathrm{~mm} / \mathrm{hr}$ in rainfall intensity) and (b) >echo level-3 (16 mm/hr).
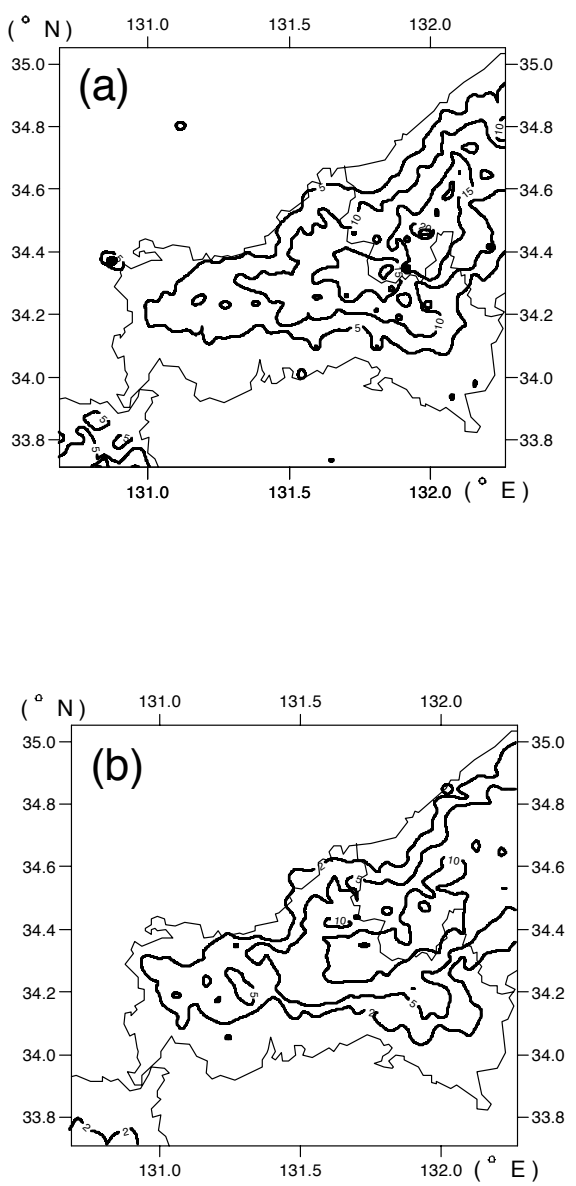

Fig. 3. Total number of days when the radar echoes (a) >echo level-1 and (b) >echo level-3 appeared. 

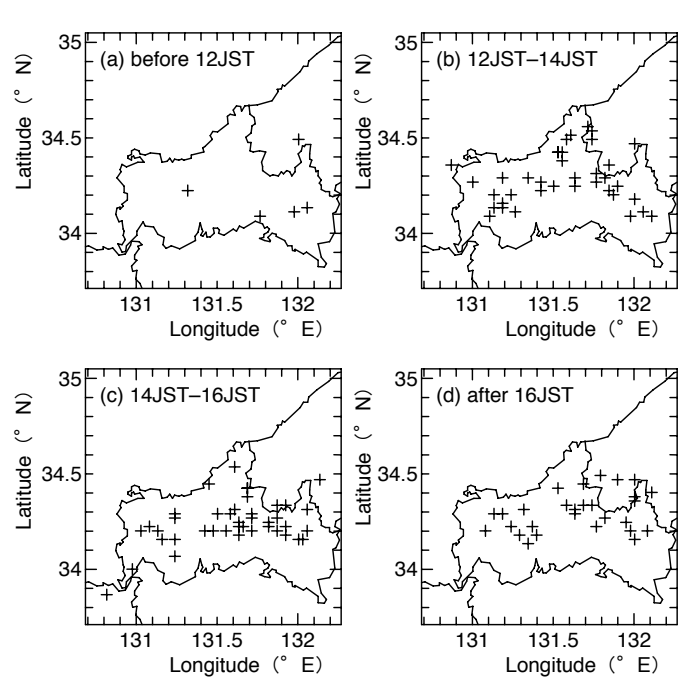

Fig. 4. Locations of the first radar echo appearances (a) before noon, (b) $12-14 \mathrm{JST}$, (c) 14 - 16JST, and (d) after 16JST.

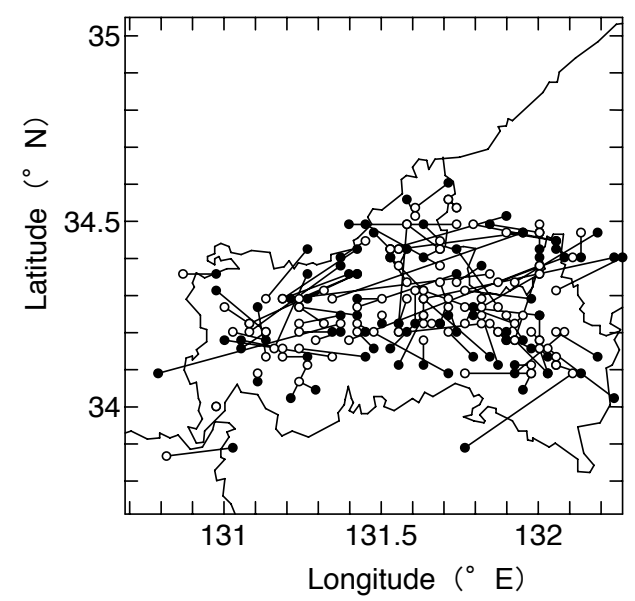

Fig. 5. Directions of radar echo traveling. White and black dots indicate locations of the radar echo appearance and disappearance, respectively.

られるような出現時間帯や標高による明確な分布の違い は山口県においてはみられない。

Fig. 5 は, 対流性降水エコーの発生地点 $(\bigcirc)$ および 消滅地点 $(○)$ の分布を示し, 二つの点を結ぶ直線は移 動方向を示す。発生地点が消滅地点に重なった場合は 白丸で示している。降水エコーの発生は山地域に集中し ており, 沿岸部で少ない。これに対しエコーの消滅は相 対的に沿岸部に分布する傾向がみられる。降水エコーの 移動方向は, 山口県内陸部の山地に沿った西南西 - 東 北東, および内陸部の山地から沿岸部に向かう 2 通りの
パターンがみられる。特に移動距離が長いものほど前者 に，短いものほど後者になる傾向がみられる。Iwasaki and Ohbayashi (1998) は降雱をもたらした積乱雲が等 高線に沿って移動する傾向があると述べているが, 本研 究においては前者のパターンがそれに類似しているといえ る。一方, 内陸から沿岸に向から動きは後述の海陸風循 環との関連が示唆される。上層の一般風との関連を調べ るために，福岡における高層気象観測データをもとに降 水エコーの移動方向打よびその速度と, 上層の風向風速 について調べたが, 明確な関係は見られなかった。むしろ, 降水エコーの寿命が長いものほど移動距離が長いことか ら, 個々の積乱雲の発達や組織化が大きく関与している のではないかと考えられる。しかしながら, さらなる議論 のためには, 再解析データや数值モデルによる再現実験 などで個々の降水エコーの発達やその移動について検証 する必要があるだろう。

\section{2 初期降水エコ一発生の時間分布}

初期降水エコー発生時刻の頻度分布を Fig. 6 に示す。 エコーの発生は午後に顕著で, 14 時から 14 時 30 分に かけてが 16 例と最も多く, 13 時から 15 時にかけての 2 時間に発生した例が $47.8 \%$ を占める。16 時 30 分から 17 時にかけて第二の極值が出現するが，18 時以降はほ とんど発生していない。関東地方における積乱雲につい て調べた Iwasaki and Ohbayashi (1998)や Saitoh and Kimura (1998)の結果によると, その発生は $16 〜 18$ 時に集中しており, 本研究で求められた第二の極值には 一致するが，第一の極值はそれより 2 〜 時間ほど早く 出現している。これは関東地方の夏期の対流性降雨が広 大な関東平野を吹く海風 (広域海風) と収束域の形成に より降雨を励起している (Fujibe et al., 2003; Nakanishi and Hara, 2003; Nakanishi and Sugaya, 2004)のに 対し, 山口県においては内陸から沿岸までの距離が短く, 対流性降雨形成の空間スケールが小さいことが一つの原 因であると考えられる。

\section{3 対流性降雨の寿命とエコ一面積の関係}

Fig. 7 は降水エコーの寿命の頻度分布を示す。60 分 から 90 分の間に極大值を持ち, ほとんどは 2 時間以内 の寿命を持つ。平均寿命は 95 分であり, Iwasaki and Ohbayashi (1998) が示した関東地方にみられる降雱を 伴う積乱雲の平均寿命 136 分に比べ 40 分程度短くなっ ている。Fig. 8 は降水エコーの寿命と最大エコー面積の 関係を示す。図中 A の実線は寿命 120 分以下の事例 に関する近似直線を示す (破線は実線 A を寿命 120 分 以降に延長したものを示す)。エコー面積が $200 \mathrm{~km}^{2}$ 以 下は全事例の $71.4 \%, 300 \mathrm{~km}^{2}$ 以下で $84.8 \%$ を占め る。発生から 120 分までは寿命が長くなるにつれてエコー 


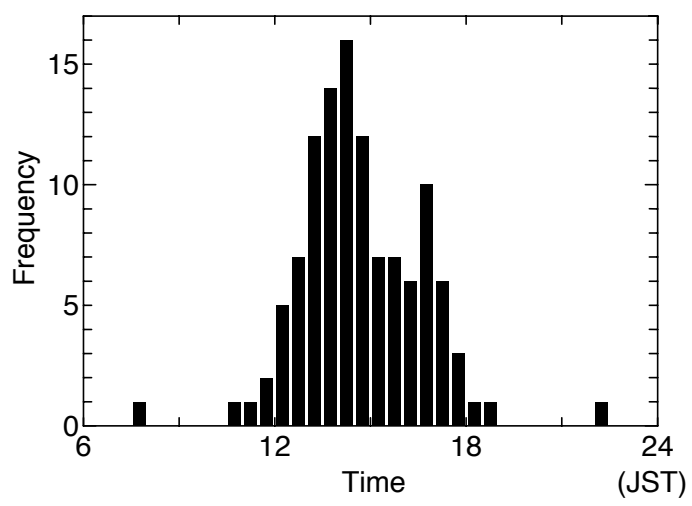

Fig. 6. Diurnal change of the frequency of the first radar echo appearances.

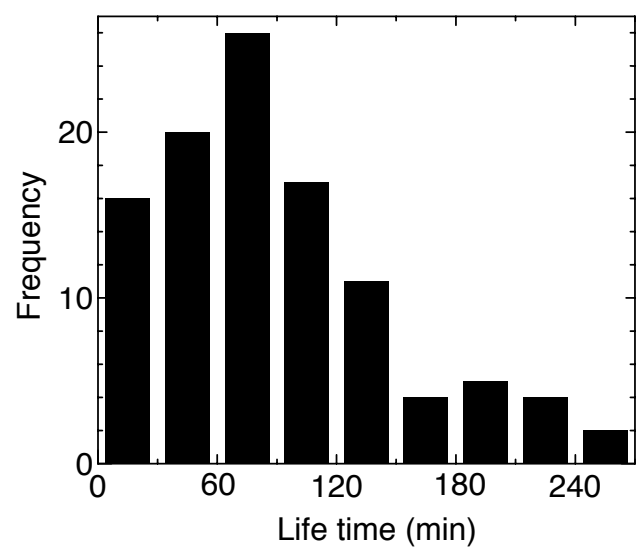

Fig. 7. Frequency of the life time of radar echoes.

面積も大きくなる傾向があるが，それ以後は，エコー面 積が破線 A で示される直線的に増加する傾向と, 極端に 増加する傾向の 2 通りに分類される。後者は発生した降 水エコーがその後組織化して長時間持続しエコー面積を 増大させた例であると考えられる。

\section{4 初期降水エコ一発生時の局地風循環}

山口県下および周辺に位置する AMeDAS 観測地点 (下関, 豊田, 油谷, 萩, 秋吉台, 山口, 防府, 須佐, 徳佐, 下松, 柳井, 玖珂, 岩国, 広瀬, 六日市, 津和野, 益田) における初期降水エコー発生時直前の風向頻度分 布 (\%) を Fig. 9 に示す。同一時間 (AMeDAS の時間分 解能 1 時間) 内に複数のレーダーエコーが発生した場合 は, 風向頻度を 1 回とし, 総事例数は 85 である。エコー 発生時の風向の特徵は, 下関を除き, 沿岸部で瀬戸内海 側, 日本海側ともに晴天日の典型的な海から内陸に向か う風 (海風) が卓越している。一方, 内陸部では, 南風 成分, 北風成分の 2 方向の風が顕著である。この風向分

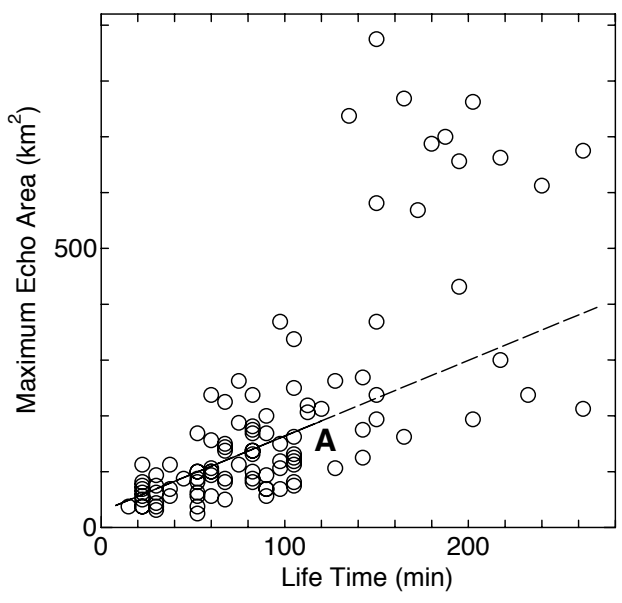

Fig. 8. Relationship between the life time and the maximum radar echo area. $\mathbf{A}$ is approximate line calculated by the data under $500 \mathrm{~km}^{2}$.

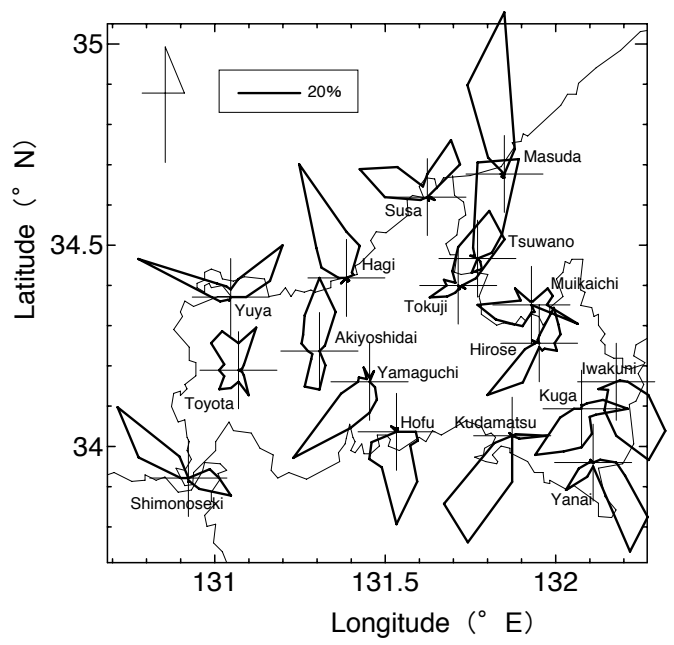

Fig. 9. Wind roses just before when the first echoes appeared in the analysis domain.

布より山口県においても海風がもたらす収束場の形成が対 流性降雨を励起していることが示唆される。しかしながら, 収束場の形成メカニズムなどの理解には関東地方に比べ 対象とするスケールの小さい山口県ではより密な風データ が必要であり, さらなる解析が必要であろう。

\section{4. まとめ}

降雱や落雷などを伴い農業気象災害をもたらすことが知 られ，また一方で，貴重な水資源ともなっている夏期の 対流性降雨に注目し，三方が海に囲まれた地理的位置に ある山口県で 1989 年から 1998 年の 7 ～月に発生し 
た対流性降雨について, 気象庁北部九州合成レーダーエ コーデータを用いてその分布, 発生, 移動および寿命を 調べた。

夏期対流性降雨の分布は, 島根県境付近に極大域を持 ち, 山口県中部を東西に伸びていた。初期降水エコーの 発生分布は降雨分布と同様で山地域に集中しており, そ の移動方向は山地に沿う東西方向および内陸から沿岸部 へ向かう 2 通りのパターンがみられた。発生は 14 時ごろ にピークがみられ，その寿命は 95 分であった。エコー面 積の変化は, 寿命が 2 時間を越えるものについてエコー 面積が急激に増大する事例もみられた。初期降水エコー 発生時には典型的な海陸風循環の海風成分がみられ, こ れによって収束場が形成されていることが示唆された。

関東地方の夏期対流性降雨と比較すると, 初期降水工 コーの発生は 2 時間程度早く, その分布は時間帯や標高 によらず，さらに寿命は 40 分程度短い傾向がみられた。 山口県における夏期の対流性降雨は関東地方に比べ時間 的, 空間的にスケールの小さいものであるといえる。これ らは広大な関東平野と急峻な山岳部がもたらす広域海風 による収束場の形成というスケールと比べ, 山口県が持つ 地形的スケールが小さく, そこに形成される局地風循環や 収束場の水平スケールの違いが大きく関与しているものと 考えられる。

\section{References}

Fujibe, F., Seko, H., and Shoji, Y., 2003: Relation between precipitation distribution and surface wind patterns in the Kanto Plain in the afternoon of summer. (in Japanese) Tenki, 50, 777-786.

Iwasaki, H., and Ohbayashi, Y., 1998: Some characteristics features of hailstorms over Gunma Prefecture. (in Japanese) Tenki, 45, 695-705.

Nakanishi, M., and Hara, Y., 2003: Characteristics of local winds associated with the intensification of short-time rainfall in the Tokyo urban area in the afternoon of summer days. (in Japanese) Tenki, 50, 91-103.

Nakanishi, M., and Sugaya, M. O., 2004: Relationship of clouds appearing around Tokyo Bay to rainfalls in the Kanto Plain, in the afternoon of summer days. (in Japanese) Tenki, 51, 729-739.

Ogura, Y., Okuyama, K., and Taguchi, A., 2002a: The thunderstorm activity observed by SAFIR and its relation to the atmospheric environment over the Kanto area in the summer. Part I: An overview of the thunderstorm activity and thunderstorm generating mechanisms. (in Japanese) Tenki, 49, 541-553.

Ogura, Y., Okuyama, K., and Taguchi, A., 2002b: The thunderstorm activity observed by SAFIR and its relation to the atmospheric environment over the Kanto area in the summer. Part III: Effects of upper-level disturbances on the thunderstorm generation. (in Japanese) Tenki, 49, 747-762.

Omoto, Y., 1968: Hailstorms in the Kanto-Koshin District (1). (in Japanese) J. Agric. Meteorol., 24, 33-38.

Omoto, Y., 1970: Hailstorms in the Kanto-Koshin District (2). (in Japanese) J. Agric. Meteorol., 26, 91-100.

Omoto, Y., 1971: Hailstorms in the Kanto-Koshin District (3). (in Japanese) J. Agric. Meteorol., 27, 211-217.

Omoto, Y., and Seino, H., 1978: On relationships between hailfall characteristics and crop damage. (in Japanese) J. Agric. Meteorol., 34, 65-76.

Sakanoue, T., 1969: Studies of hail damage at Chikugo District, Fukuoka Prefecture. (in Japanese) J. Agric. Meteorol., 25, 19-30.

Saitoh, T., and Kimura, F., 1998: Diurnal variation of convective precipitation in Chubu-Kanto area in the summer. (in Japanese) Tenki, 45, 541-549.

Seino, H., 1980: On the characteristics of hail size distribution related to crop damage. J. Agric. Meteorol., 36, 81-88.

Seino, H., 1985: Experimental study on crop damage by hail Part I. The effect of simulated hailfall on crop yield. J. Agric. Meteorol., 40, 361-368.

Taguchi, A., Okuyama, K., and Ogura, Y., 2002: The thunderstorm activity observed by SAFIR and its relation to the atmospheric environment over the Kanto area in the summer. Part II: Thunderstorm prediction by stability indices. (in Japanese) Tenki, 49, 649-659. 